\title{
Pengaruh Penambahan Mikroenkapsulasi Minyak Kanola Terhadap Performa. Kecernaan Nutrien, dan Profil Asam Lemak Rumen Domba
}

\author{
Vishara Sekar Fadhilah ${ }^{1}$, I Komang Gede Wiryawan ${ }^{2}$, Sri Suharti ${ }^{2}$ \\ Departemen Ilmu Nutrisi dan Teknologi Pakan, IPB University \\ Kampus IPB Dramaga, Bogor, Indonesia \\ *Email korespondensi: harti_ss@yahoo.com
}

(Diterima: 24-07-2019; disetujui 20-08-2019)

\begin{abstract}
ABSTRAK
Penelitian ini bertujuan untuk menyelidiki pengaruh dari pemberian pakan yang mengandung mikroenkapsulasi minyak kanola pada konsumsi, kecernaan nutrient, dan performa pertumbuhan pada domba. Lima belas domba garut jantan dengan rataan bobot badan awal 20,17 $\pm 4,65 \mathrm{~kg}$ digunakan dalam rancangan acak kelompok (RAK) pada periode pemeliharaan selama 100 hari dengan 3 perlakuan dan 5 kelompok sebagai ulangan. Perlakuan yang digunakan adalah P0 (kontrol/hijauan: konsentrat $=60: 40$ ), P1 (P0 mengandung 4\% minyak kanola), dan P2 (P0 mengandung 4\% mikroenkapsulasi minyak kanola). Hasil yang diperoleh dalam penelitian ini menunjukkan bahwa tidak ada perbedaan untuk performa. Konsumsi, dan kecernaan nutrien. Suplementasi minyak kanola murni maupun terenkapsulasi sebagai sumber energi dalam ransum domba, menghasilkan pertambahan bobot badan harian (PBBH) dan efisiensi penggunaan pakan yang terbaik. Proporsi asam lemak tak jenuh pada perlakuan suplementasi mikroenkapsulasi minyak kanola 8\% lebih tinggi dibandingkan dengan kontrol. Perlakuan minyak kanola murni meningkatkan $(\mathrm{P}<0,05)$ proporsi asam stearat $(\mathrm{C} 18: 0)$ dibandingkan perlakuan lainnya. Sehingga. dapat disimpulkan bahwa suplementasi $4 \%$ mikroenkapsulasi minyak kanola di dalam ransum. selaian menghasilkan PBBH dan efisiensi pakan terbaik juga mampu melindungi asam lemak tak jenuh (ALTJ) dari proses biohidrogenasi rumen tanpa mengganggu konsumsi dan kecernaan nutrient ransum.
\end{abstract}

Kata kunci: konsumsi, kecernaan, mikroenkapsulasi, minyak kanola, performa

\begin{abstract}
The aim of this study was to investigate the effects of feeding diets with microencapsulation of canola oil on intake, nutrient apparent digestibility, and growth performance of lambs. Fifteen male garut lambs with an initial average body weight of $20.17 \pm 4.65 \mathrm{~kg}$ were used in a randomized block design (RBD) for a 100-days feeding period with 3 treatments and 5 groups as replication. The treatments were P0 (control/forage:concentrate $=60: 40), \mathrm{P} 1$ (P0 contained $4 \%$ of canola oil), and P2 (P0 contained 4\% of microencapsulated canola oil). The results showed that there was no difference in the growth performance, intake, and digestibility of nutrients. The best of average daily gain (ADG) and feed efficiency results from the supplementation of pure canola oil or encapsulated canola oil in diets. The proportion of unsaturated fatty acids in the supplementation of microencapsulated canola oil treatment was $8 \%$ higher than control. The treatment of canola oil supplementation increased $(\mathrm{P}<0.05)$ the proportion of stearic acid (C18:0) compared to other treatments. Thus, it can be concluded that supplementation of $4 \%$ of microencapsulated canola oil, besides produced the best of ADG and feed efficiency, was also able to maintain unsaturated fatty acids from the rumen biohydrogenation process without detrimental effects on nutrient intake and digestibility in lambs.
\end{abstract}

Keywords: canola oil, digestibility, intake, microencapsulation, performance 


\section{PENDAHULUAN}

Pada fase pertumbuhan dengan tingkat produksi yang tinggi ternak ruminansia membutuhkan suplai energi yang lebih banyak. Kualitas hijauan di daerah tropis (serat kasar tinggi dan protein rendah) tidak mampu mencukupi kebutuhan ternak yang sedang tumbuh. Hal tersebut diperparah dengan tingginya proporsi konsumsi hijauan seperti yang telah dilaporkan Sudarman \& Ito (2000). Pemberian sumber energi yang lebih mudah tersedia di dalam rumen seperti lemak dapat digunakan sebagai upaya untuk mengurangi keterbatasan suplai energi dalam ransum ruminansia. Menurut NRC (2001) energi yang terkandung dalam lemak sedikitnya dua kali lebih besar dibanding karbohidrat, dengan panas metabolis yang dihasilkan lebih rendah sehingga dapat mencegah ternak mengalami heat stress.

Minyak nabati dapat digunakan sebagai sumber energi pendukung di dalam pakan untuk memenuhi kebutuhan energi yang tinggi. Asam lemak tak jenuh (ALTJ) pada ternak ruminansia. berpotensi sebagai sumber energi alternatif tanpa menghambat proses fermentasi di rumen yang dapat menyebabkan penurunan degradabilitas serat (Jenkins, 1993). Menurut O'Brien (2009). minyak kanola mengandung $60,9 \%$ oleat (C18:1), 21,0\% linoleat (C18:2), dan 8,8\% linolenat (C18:3). Jumlah penambah-an minyak sangatlah terbatas pada ransum ternak ruminansia yaitu 5\% dari bahan kering ransum. sedangkan sumber asam lemak terproteksi tidak lebih dari $10 \%$ di dalam konsentrat (Lubis \& Wina 1998). Eastridge \& Firkins (1991) menjelaskan bahwa kandungan ALTJ dalam minyak nabati bersifat racun bagi sebagian besar mikroba rumen dan dapat menyelimuti partikel serat sehingga menurunkan aktivitas bakteri fibrolitik dalam mencerna serat. Lebih lanjut Sudibya et al. (2009) melaporkan bahwa penggunaan minyak dalam jumlah yang besar akan mengalami hidrogenasi (pengubahan asam lemak tidak jenuh menjadi asam lemak jenuh) di dalam rumen. Asam lemak jenuh (ALJ) hasil proses biohidrogenasi tersebut nantinya akan dideposit di dalam jaringan tubuh termasuk otot atau daging ternak. Oleh sebab itu penambahan lemak berupa minyak kanola perlu diproteksi sehingga dapat melewati rumen tanpa memberikan pengaruh negatif terhadap mikroba rumen dan terhindar dari proses biohidrogenasi.

Mikroenkapsulasi merupakan salah satu metode proteksi yang telah umum digunakan. Agnihotri et al. (2012) menjelaskan bahwa metode mikroenkapsulasi selain bertujuan untuk menghindari proses biohidrogenasi di rumen. juga dapat menghindari penurunan aktivitas mikroba. serta penurunan kecernaan pakan. Pada penelitian sebelumnya. Hidayah et al. (2014) melaporkan bahwa minyak wijen yang diproteksi dengan mikroenkapsulasi dapat meningkatkan kandungan asam oleat (C18:1) akibat adanya akumulasi dari proses biohidrogenasi asam linoleat (C18:2) yang dapat membentuk asam vasenat. Suharti et al. (2015) menambahkan bahwa suplementasi $6 \%$ minyak kanola yang terproteksi sabun kalsium tidak mengganggu populasi mikroba rumen dan cenderung meningkatkan aktivitas fermentasi mikroba rumen. Penambahan mikroenkapsulasi minyak kanola dalam ransum ruminansia yaitu selain sebagai sumber energi alternatif. ALTJ yang terkandung dalam minyak kanola diharapkan dapat mengalami by pass, dicerna pascarumen, dan dimanfaatkan ternak. Informasi mengenai suplementasi mikroenkapsulasi minyak kanola pada ransum domba belum banyak dilaporkan. Hal tersebut yang melatarbelakangi dilakukannya penelitian mengenai pemberian ransum yang mengandung mikroenkapsulasi minyak kanola pada ternak domba secara in vivo. Tujuan dari penelitian ini yaitu untuk menganalisis potensi minyak kanola sebagai sumber energi dan sumber asam lemak tak jenuh dengan metode proteksi mikroenkapsulasi terhadap performa, kecernaan nutrien, dan profil asam lemak cairan rumen domba.

\section{MATERI DAN METODE}

\section{Materi Penelitian}

Penelitian ini menggunakan 15 ekor domba garut jantan berumur 6-8 bulan dengan bobot badan awal $20,17 \pm 4,65 \mathrm{~kg}$ yang ditempatkan di kandang individu yang dialokasikan secara acak ke dalam 3 macam perlakuan dan 5 ulangan. Setiap ternak ditempatkan pada kandang individu dengan ukuran $120 \mathrm{~cm} \times 60 \mathrm{~cm}$ yang telah dilengkapi tempat pakan dan air minum. serta tempat penampung feses. Bahan yang digunakan dalam pembuatan mikroenkapsulasi minyak kanola adalah minyak kanola. bahan penyalut berupa gum arab, dan maltodektrin, serta air.

\section{Metode Penelitian}

Pembuatan formulasi ransum (Tabel 1) mengacu pada Kearl (1982) untuk kebutuhan 
domba pedaging dengan bobot badan $20 \mathrm{~kg}$ dengan PBBH 50 g ekor $^{-1}$ hari $^{-1}$ dengan proporsi hijauan: konsentrat (60:40). Pembuatan mikroenkapsulasi minyak kanola mengacu pada metode Carneiro et al. (2013). Minyak kanola dihomogenisasi dengan bahan penyalut berupa gum arab dan maltodekstrin (50:50) di dalam pelarut air kemudian dikeringkan menggunakan spray dryer dengan suhu inlet $180^{\circ} \mathrm{C} \pm 5^{\circ} \mathrm{C}$ dan outlet $80^{\circ} \mathrm{C} \pm 5^{\circ} \mathrm{C}$. Rasio bahan penyalut sebesar $11,76 \%$ bahan inti berupa minyak kanola $5,88 \%$, dan air 82,36\% (Hidayah et al., 2014).

Pemeliharaan domba dilakukan selama 100 hari dengan masa adaptasi ransum perlakuan selama 14 hari. Setiap domba diberi obat cacing sebanyak $\pm 10 \mathrm{ml} \mathrm{ekor}^{-1}$ dan dimasukkan ke dalam kandang individu. Pakan diberikan sebanyak 3\% bahan kering dari bobot badan ternak dan pemberian air minum secara $a d$ libitum. Penimbangan bobot badan dilakukan setiap bulan untuk mengukur pertambahan bobot badan harian $(\mathrm{PBBH})$.
Koleksi Feses. Koleksi feses dilakukan untuk mengetahui kecernaan bahan kering dan nutrien lain dalam ransum perlakuan dengan membandingkan jumlah pakan yang dikonsumsi dan yang dikeluarkan sebagai feses. Selama 7 hari di akhir masa pemeliharaan dilakukan koleksi feses total. Sampel feses yang terkumpul kemudian ditimbang dan diambil 10\% dari total feses tiap ekor domba setiap harinya lalu dikeringkan dan dilakukan perhitungan kandungan bahan kering dan bahan organik yang mengikuti prosedur AOAC (2000).

Pengambilan cairan rumen dilakukan pada waktu 4 jam setelah pemberian pakan pagi (after morning feeding) di hari terakhir masa pemeliharaan dan berpedoman pada metode stomach tube (Preston, 1986). Profil asam lemak diukur menggunakan alat Gas Chromatography (GC type Claurus 580) dengan kolom polyetilen glycol $(30 \mathrm{~m} \times 0,25 \mathrm{~mm} \times 0,25 \mu \mathrm{m})$ yang preparasi sampelnya menurut metode hidrolisis Weibull.

Tabel 1. Komposisi dan kandungan ransum mengandung minyak kanola murni maupun minyak kanola terenkapsulasi berdasarkan bahan kering

\begin{tabular}{|c|c|c|c|}
\hline \multirow{3}{*}{ Nama Bahan Pakan } & \multicolumn{3}{|c|}{ Perlakuan } \\
\hline & \multicolumn{3}{|c|}{ Jumlah Komposisi Ransum (\%) } \\
\hline & $\mathrm{P} 0$ & P1 & $\mathrm{P} 2$ \\
\hline Rumput gajah & 60 & 60 & 60 \\
\hline Bungkil kedelai & 0 & 4,1 & 0 \\
\hline Bungkil kelapa & 12 & 2,2 & 12 \\
\hline Bungkil sawit & 4,2 & 8,8 & 10 \\
\hline Dedak halus & 0 & 8 & 0 \\
\hline Pollard & 11,3 & 8,4 & 10,1 \\
\hline Molases & 4 & 4 & 3,4 \\
\hline Urea & 0,2 & 0,2 & 0.2 \\
\hline Jagung & 8 & 0 & 0 \\
\hline $\mathrm{DCP}$ & 0,3 & 0,3 & 0,3 \\
\hline Minyak kanola & 0 & 4 & 0 \\
\hline Mikroenkapsulasi minyak kanola & 0 & 0 & 4 \\
\hline Total & 100 & 100 & 100 \\
\hline \multicolumn{4}{|l|}{ Kandungan nutrient (\% BK) } \\
\hline Bahan Kering & 45,88 & 46,28 & 46,32 \\
\hline Protein Kasar & 10,95 & 12,95 & 11,10 \\
\hline Lemak Kasar & 4,06 & 7,04 & 5,60 \\
\hline Serat Kasar & 19,91 & 20,21 & 20,34 \\
\hline Abu & 10,81 & 11,54 & 10,70 \\
\hline BETN & 54,27 & 48,27 & 52,26 \\
\hline TDN & 64,93 & 67,51 & 67,31 \\
\hline \multicolumn{4}{|l|}{ Asam Lemak (\% total lemak) } \\
\hline ALJ & 43,35 & 21,99 & 46,07 \\
\hline ALTJ & 56,65 & 78,01 & 53,93 \\
\hline
\end{tabular}

P0= Ransum kontrol (60\% hijauan : 40\% konsentrat); P1= P0 mengandung 4\% Minyak Kanola; P2= P0 mengandung 4\% Minyak Kanola Terenkapsulasi, BETN= Bahan Ekstrak Tanpa Nitrogen; TDN= Total Digestible Nutrient yang dihitung berdasarkan Hartadi (1980); ALJ= Asam Lemak Jenuh; ALTJ= Asam Lemak Tak Jenuh 


\section{HASIL DAN PEMBAHASAN}

\section{Konsumsi Nutrien}

Konsumsi bahan kering konsentrat dan hijauan tidak berbeda antar perlakuan dengan penambahan $4 \%$ minyak kanola maupun mikroenkapsulasi minyak kanola (Tabel 2). Hasil tersebut menunjukkan bahwa penambahan minyak kanola dengan atau tanpa proteksi dalam taraf $4 \%$ di dalam ransum tidak memberikan pengaruh negatif terhadap palatabilitas ransum tersebut. Rataan konsumsi ransum dalam penelitian ini berkisar antara 2,56-2,64\% dari bobot badan domba dengan rasio hijauan : konsentrat yaitu 58\% : 42\%. Rasio tersebut mendekati target awal penelitian yaitu sebesar $60 \%$ : $40 \%$. Rendahnya rataan konsumsi $(<3 \%$ BB) menunjukkan bahwa selama masa pemeliharaan terjadi penurunan konsumsi ransum yang merata pada setiap perlakuan yang tidak disebabkan oleh adanya suplementasi minyak kanola maupun mikroenkapsulasi minyak kanola. Pada penelitian ini penambahan
4\% minyak kanola maupun mikroenkapsulasi minyak kanola tidak menunjukkan penurunan konsumsi bahan kering ransum (Tabel 3). Hasil yang serupa diperoleh Maia et al. (2012) yang menyatakan bahwa suplementasi minyak kanola. minyak bunga matahari. dan minyak castor sebanyak $30 \mathrm{~g} \mathrm{~kg}^{-1} \mathrm{BK}$ dalam ransum domba tidak mempengaruhi konsumsi bahan kering dan nutrien lain kecuali lemak kasar yang lebih besar pada ternak yang menerima minyak. Lin et al. (2013) menambahkan bahwa suplementasi kombinasi minyak esensial terenkapsulasi di dalam konsentrat tidak mempengaruhi konsumsi bahan kering yang menunjukkan bahwa enkapsulasi merupakan metode efektif dalam memecahkan masalah palatabilitas yang disebabkan oleh minyak esensial. Penambahan minyak kanola maupun mikroenkapsulasi minyak kanola tidak berpengaruh terhadap konsumsi bahan kering dan nutrien lain, tetapi meningkatkan $(\mathrm{P}<0,05)$ konsumsi protein dan lemak (Tabel 3).

Tabel 2. Rataan konsumsi bahan kering hijauan dan konsentrat domba dengan penambahan minyak kanola dan mikroenkapsulasi minyak kanola (g ekor ${ }^{-1}$ hari $\left.^{-1}\right)$

\begin{tabular}{lccccc}
\hline & \multicolumn{3}{c}{ Konsumsi } & \% Rasio & $\begin{array}{c}\text { \% bobot } \\
\text { badan }\end{array}$ \\
\cline { 2 - 6 } & Hijauan & Konsentrat & Total Pakan & H:K & \\
\hline P0 & $390,70 \pm 58,21$ & $301,10 \pm 45,14$ & $691,80 \pm 63,36$ & $56: 44$ & 2,72 \\
P1 & $423,01 \pm 61,50$ & $285,94 \pm 56,29$ & $708,95 \pm 96,92$ & $60: 40$ & 2,64 \\
P2 & $391,96 \pm 45,41$ & $287,87 \pm 57,87$ & $679,83 \pm 73,60$ & $58: 42$ & 2,56 \\
\hline
\end{tabular}

$\mathrm{P} 0=$ Ransum kontrol (60\% hijauan : 40\% konsentrat); P1= P0 mengandung 4\% Minyak Kanola; P2= P0 mengandung 4\% Minyak Kanola Terenkapsulasi; H= Hijauan; K= Konsentrat

Tabel 3. Rataan konsumsi dan kecernaan nutrien ransum domba dengan penambahan minyak dan mikroenkapsulasi minyak kanola

\begin{tabular}{lccc}
\hline \multicolumn{1}{c}{ Peubah } & \multicolumn{3}{c}{ Perlakuan } \\
\cline { 2 - 4 } & P0 & P1 \\
\hline Konsumsi g ekor hari $^{-1}$ & $691,80 \pm 59,29$ & $708,96 \pm 117,19$ & $679,84 \pm 99,24$ \\
Bahan Kering & $77,50 \pm 6,89^{\mathrm{b}}$ & $91,94 \pm 15,71^{\mathrm{a}}$ & $75,69 \pm 11,22^{\mathrm{b}}$ \\
Protein Kasar & $24,83 \pm 1,95^{\mathrm{c}}$ & $42,78 \pm 10,54^{\mathrm{a}}$ & $36,73 \pm 8,58^{\mathrm{b}}$ \\
Lemak Kasar & $132,48 \pm 15,73$ & $142,80 \pm 21,83$ & $135,02 \pm 17,08$ \\
Serat Kasar & & & \\
Kecernaan (\%) & $65,19 \pm 5,70$ & $57,21 \pm 6,51$ & $60,42 \pm 11,25$ \\
Bahan Kering & $63,61 \pm 6,20$ & $61,07 \pm 6,50$ & $59,57 \pm 8,30$ \\
Protein Kasar & $82,05 \pm 4,82$ & $81,01 \pm 5,51$ & $82,26 \pm 3,33$ \\
Lemak Kasar & $54,46 \pm 9,03$ & $46,76 \pm 6,21$ & $51,50 \pm 8,31$ \\
Serat Kasar & $63,64 \pm 5,07$ & $60,08 \pm 6,45$ & $65,70 \pm 5,92$ \\
TDN & &
\end{tabular}

$\mathrm{P} 0=$ Ransum kontrol (60\% hijauan : 40\% konsentrat); P1= P0 mengandung 4\% Minyak Kanola; $\mathrm{P} 2=\mathrm{P} 0$ mengandung 4\% Minyak Kanola Terenkapsulasi; TDN= Total Digestible Nutrient. Huruf yang berbeda pada baris yang sama menunjukkan berbeda nyata $(\mathrm{P}<0,05)$ 
Palmquist \& Jenkins (1980) menjelaskan bahwa suplementasi lemak di dalam ransum dapat menurunkan konsumsi dan kecernaan bahan kering ketika kandungan lemak kasar lebih besar dari $70 \mathrm{~g} \mathrm{~kg}^{-1} \mathrm{BK}$ di dalam ransum. Pada penelitian ini, kandungan lemak kasar ransum yang mengandung minyak kanola murni maupun minyak kanola terenkapsulasi tidak lebih dari 7\% BK yang dapat menjelaskan bahwa penambahan minyak kanola yang kaya akan asam lemak tak jenuh tidak menurunkan konsumsi nutrien ransum. Hasil penelitian ini serupa dengan yang telah dilaporkan Machmüller \& Kreuzer (1999) bahwa pemberian ransum yang mengandung $30-35 \mathrm{~g} \mathrm{~kg}^{-1}$ minyak kelapa tidak mempengaruhi konsumsi bahan kering pada domba dewasa, sedangkan penambahan $70 \quad \mathrm{~g} \quad \mathrm{~kg}^{-1}$ minyak kelapa menurunkan palatabilas ransum. Selain itu, rasio $60 \%$ hijauan pada penelitian ini juga dapat menekan efek negatif yang ditimbulkan dari penambahan minyak kanola yang tinggi kandungan asam lemak tak jenuh. Messana et al. (2013) menjelaskan rasio hijauan yang lebih tinggi dibandingkan konsentrat dapat menurunkan efek merugikan yang ditimbulkan oleh asam lemak tak jenuh ganda (Poly unsaturated fatty acid) pada fermentasi rumen karena fraksi serat yang besar menciptakan lingkungan yang memungkinkan PUFA dapat dihidrolisis dan dibiohidrogenasi oleh mikroba rumen. Hasil konsumsi semua nutrien kecuali protein dan lemak yang tidak berbeda antar perlakuan disebabkan oleh kandungan nutrien ransum yang relatif sama. Suplementasi minyak kanola maupun mikroenkapsulasi minyak kanola pada taraf $4 \%$ meningkatkan kandungan lemak kasar ransum yang mengakibatkan peningkatan konsumsi lemak kasar dibandingkan dengan kontrol. Peningkatan konsumsi protein pada penelitian ini diduga tidak disebabkan oleh adanya suplementasi minyak kanola murni maupun mikroenkapsulasi minyak kanola, melainkan disebabkan oleh perbedaan bahan penyusun ransum perlakuan sehingga menghasilkan kandungan protein kasar yang tidak seragam (iso protein) antar perlakuan.

\section{Kecernaan Nutrien Ransum}

Penambahan minyak kanola maupun mikroenkapsulasi minyak kanola $4 \%$ dalam ransum domba tidak mempengaruhi kecernaan nutrien ransum (Tabel 3). Hasil tersebut menunjukkan bahwa penambahan minyak kanola murni maupun yang terproteksi mikroenkapsulasi dapat menjaga keseimbangan mikroorganisme rumen sehingga diperoleh hasil kecernaan yang sama dengan kontrol. Tingginya rasio hijauan dalam penelitian ini dapat menjelaskan hasil yang diperoleh. Menurut Bateman \& Jenkins (1998) kandungan serat yang tinggi memungkinkan untuk bersaing dengan pengikatan partikel pakan oleh asam lemak di dalam rumen, sehingga dapat mencegah gangguan pada kecernaan serat. Kecernaan lemak pada perlakuan suplementasi minyak kanola lebih rendah dibandingkan dengan kontrol dan mikroenkapsulasi minyak kanola. Hasil yang berbeda diperoleh oleh Adeyemi et al. (2016) bahwa terjadi peningkatan konsumsi dan kecernaan LK ransum kambing dengan meningkatnya suplementasi campuran minyak kanola dan minyak sawit. Kronfeld et al. (2004) menambahkan bahwa peningkatan kecernaan lemak berhubungan dengan peningkatan konsumsi lemak yang terjadi karena peningkatan aktivitas lipase karena peningkatan konsentrasi substrat, dilusi lemak endogen, dan/atau ketersediaan asam lemak untuk penyerapan.

Kecernaan serat kasar pada setiap perlakuan tidak menunjukkan perbedaan yang nyata. namun kecernaan serat pada perlakuan mikroenkapsulasi minyak kanola cenderung meningkat dibandingkan dengan minyak kanola tanpa proteksi. Hasil penelitian Suharti et al. (2018) menunjukkan bahwa penggunaan sabun kalsium sebagai metode proteksi lemak mampu meniadakan efek negatif asam lemak terhadap populasi bakteri, sehingga kecernaan serat dalam ransum dapat meningkat. Kecernaan TDN yang tidak berbeda nyata antar perlakuan sejalan dengan konsumsi dan kandungan TDN dalam ransum yang relatif sama. Menurut Kearl (1982) kebutuhan energi dalam bentuk TDN untuk domba penggemukan yaitu sebesar $47 \%$. Data hasil perhitungan pada penelitian ini menunjukkan bahwa nilai TDN dalam ransum perlakuan telah memenuhi standar. Hasil dalam penelitian ini menunjukkan bahwa suplementasi 4\% minyak kanola murni maupun yang diproteksi dengan mikroenkapsulasi belum mengganggu kecernaan nutrien ransum. Sebaliknya Kurniawati et al. (2018) melaporkan bahwa penambahan minyak esensial yang berasal dari Foeniculum vulgare, Pinus merkusii, Cymbopogon nardus, dan Melaleuca leucadendra dalam berbagai taraf menurunkan $\mathrm{KCBK}, \mathrm{KCBO}$, dan kecernaan serat secara in vitro. Perbedaan hasil yang diperoleh pada suplementasi berbagai minyak esensial terhadap 
kecernaan nutrien dapat dipengaruhi oleh beberapa faktor seperti asal tanaman, komponen bioaktif, dan level penambahan minyak yang menyebabkan hasil yang bervariasi (Castillejos et al., 2007).

\section{Performa dan Efisiensi Pakan}

Perlakuan penambahan lemak berupa $4 \%$ minyak kanola maupun mikroenkapsulasi minyak kanola tidak menunjukkan hasil yang berbeda terhadap PBBH dan efisiensi pakan antar perlakuan (Tabel 4). Hasil penelitian sebelumnya menyatakan bahwa penambahan lemak di dalam ransum domba penggemukan tidak menyebabkan modifikasi terhadap performa maupun karakteristik karkas (Boles et al., 2005; Castro et al., 2005). Penambahan 4\% minyak kanola dengan atau tanpa proteksi mikroenkapsulasi menghasilkan PBBH yang lebih besar dibandingkan dengan perlakuan kontrol. Dutta et al. (2008) menambahkan bahwa terjadi peningkatan PBBH kambing secara bertahap dengan suplementasi minyak kelapa sawit hingga $50 \mathrm{~g} \mathrm{~kg}^{-1}$ dalam ransum, namun pada tingkat suplementasi yang lebih tinggi terjadi penurunan pertumbuhan. Begitu pun terhadap peubah efisiensi pakan tidak terdapat perbedaan yang signifikan diantara perlakuan. Hasil efisiensi pakan yang tidak jauh berbeda dari tiap perlakuan dalam penelitian ini sejalan dengan konsumsi bahan kering dan PBBH antara perlakuan yang tidak berbeda nyata.

\section{Profil Asam Lemak Cairan Rumen}

Penambahan $4 \%$ minyak kanola maupun mikroenkapsulasi minyak kanola tidak mempengaruhi proporsi asam lemak jenuh dan asam lemak tak jenuk di dalam rumen, namun kandungan stearat menurun $(\mathrm{P}<0,05)$ pada perlakuan mikroenkapsulasi minyak kanola (Tabel 5). Proporsi ALTJ yang dihasilkan pada mikroenkapsulasi minyak kanola cenderung meningkat dibandingkan perlakuan minyak kanola tanpa proteksi dan kontrol. Berdasarkan Tabel 1 dan Tabel 5 dapat diketahui bahwa penurunan persentase ALTJ pada perlakuan minyak kanola murni selama proses fermentasi di rumen yaitu sebesar $90,40 \%$, sedangkan penurunan pada perlakuan mikroenkapsulasi minyak kanola sebesar $67,88 \%$. Hasil tersebut menunjukkan bahwa dengan adanya proteksi minyak kanola lebih mampu mempertahankan ALTJ dari proses degradasi dan biohidrogenasi oleh mikroba di dalam rumen. Hasil yang serupa dilaporkan oleh Gawad et al. (2015) bahwa pengguaan alginat atau kalsium karaginan sebagai penyalut enkapsulasi minyak biji rami efektif dalam melindungi asam lemak tak jenuh ganda dari proses biohidrogenasi rumen dan transformasi ke bentuk jenuh. ikatan antara gum arab dan maltodekstrin yang kuat sebagai bahan penyalut dalam mikroenkapsulasi minyak kanola diduga efektif dalam melindungi ALTJ selama proses fermentasi di dalam rumen.

Proporsi stearat pada perlakuan minyak kanola tanpa proteksi nyata $(\mathrm{P}<0,05)$ meningkat dibandingkan perlakuan mikroenkapsulasi minyak kanola dan kontrol (Tabel 5). Hasil tersebut menunjukkan bahwa minyak kanola tanpa proteksi tidak mampu mempertahankan kandungan ALTJ selama proses biohidrogenasi sehingga proporsi asam stearat meningkat tajam sebagai akumulasi dari hidrogenasi ikatan rangkap trans-11 C18:1 (asam vasenat) di dalam rumen. Konsentrasi asam oleat (C18:1) tertinggi diperoleh pada perlakuan suplementasi mikroenkapsulasi minyak kanola yang dijelaskan oleh Hidayah (2014) bahwa tingginya kandungan oleat (C18:1) diduga merupakan akumulasi dari proses biohidrogenasi linoleat (C18:2) dan linolenat (C18:3) yang berbentuk produk asam vasenat (trans-11 C18:1). Menurut Hobson (1988) proses biohidrogenasi asam linoleat (C18:2) dimulai dari proses isomerisasi ikatan cis-12 menjadi trans-11 yang menghasilkan cis-9, trans-11 conjugated linoleic acid (CLA), kemudian dilanjutkan proses reduksi CLA menjadi asam lemak trans11 (asam vasenat trans-11 C18:1) yang diakhiri oleh proses hidrogenisasi ikatan rangkap trans11 menjadi asam stearat (C18:0). Hasil pada penelitian ini sejalan dengan yang dilaporkan oleh Adeyemi et al. (2016) bahwa stearat memiliki konsentrasi yang paling tinggi di rumen kambing dengan meningkatnya taraf suplementasi campuran minyak kanola dan minyak sawit. Tingginya jumlah stearat yang diperoleh dalam cairan rumen menunjukkan tingginya aliran sterat ke duodenum yang nantinya akan diserap dan dideposisi di jaringan tubuh ternak. Menurut Loor et al. (2002) tingkat biohidrogenasi tergantung pada tingkat perlindungan yang diberikan oleh matriks dimana bahan inti terkandung, sehingga kemungkinan terjadinya biohidrogenasi pada mikroenkapsulasi minyak kanola terjadi lebih lambat dibandingkan minyak kanola tanpa proteksi. 
Tabel 5. Proporsi asam lemak rumen pada dengan penambahan minyak kanola dengan atau tanpa proteksi mikroenkapsulasi (\% total lemak) dengan atau tanpa proteksi mikroenkapsulasi (\% total lemak)

\begin{tabular}{lccccc}
\hline \multirow{2}{*}{ Perlakuan } & \multicolumn{5}{c}{ Peubah } \\
\cline { 2 - 6 } & \multirow{2}{*}{ ALJ } & ALTJ & Stearat (C18:0) & Oleat (C18:1) & $\begin{array}{c}\text { Linoleat } \\
(\mathrm{C} 18: 2)\end{array}$ \\
\hline P0 & $90,68 \pm 4,75$ & $9,32 \pm 4,75$ & $39,83 \pm 9,95 \mathrm{~b}$ & $7,18 \pm 3,73$ & $2,05 \pm 1,16$ \\
P1 & $92,51 \pm 1,20$ & $7,49 \pm 1,20$ & $63,40 \pm 5,11^{\mathrm{a}}$ & $4,79 \pm 0,42$ & $2,10 \pm 0,87$ \\
P2 & $82,68 \pm 9,77$ & $17,32 \pm 9,77$ & $29,56 \pm 10,70^{\mathrm{b}}$ & $12,13 \pm 6,79$ & $3,75 \pm 1,79$ \\
\hline
\end{tabular}

P0= Ransum kontrol (60\% hijauan : 40\% konsentrat); P1= P0 mengandung 4\% Minyak Kanola; P2= P0 mengandung 4\% Minyak Kanola Terenkapsulasi; ALJ= Asam Lemak Jenuh; ALTJ= Asam Lemak Tak Jenuh; Huruf yang berbeda pada kolom yang sama menunjukkan berbeda nyata $(\mathrm{P}<0.05)$

\section{KESIMPULAN}

Suplementasi $4 \%$ minyak kanola murni maupun mikroenkapsulasi minyak kanola sebagai sumber energy memberikan pengaruh positif terhadap performa domba dengan nilai PBBH dan efisiensi pakan yang lebih baik. Metode mikroenkapsulasi pada minyak kanola mampu melindungi asam lemak tak jenuh dari proses biohidrogenasi rumen sehingga menghasilkan proporsi asam stearat yang lebih rendah dibandingkan dengan minyak kanola tanpa proteksi.

\section{DAFTAR PUSTAKA}

Adeyemi. K.D., A.Q. Sazili, M. Ebrahimi. A.A. Samsudin, A.R. Alimon,. R. Karim, S.A. Karsani, \& A.B. Sabow. 2016. Effects of blend of canola oil and palm oil on nutrient intake and digestibility. growth performance. rumen fermentation and fatty acids in goats. Anim. Sci. J. 87(9): 1137-1147.

Agnihotri, N., R. Mishra, C. Goda, \& M. Arora. 2012. Microencapsulation-A novel approach in drug delivery: a review. Indo Global J. Phram. Sci. 2(1):1-20.

AOAC. 2000. Official Method of Analysis. 13 ${ }^{\text {th }}$ Ed. Association of Official Analytical Chemist Press. Washington. D.C.

Bateman. H.G. \& T.C. Jenkins. 1998. Influence of soybean oil in high fiber diets fed to nonlactating cows on ruminal unsaturated fatty acids and nutrient digestibility. J. Dairy Sci. 81: 2451-2458.

Boles. J.A., R.W. Kott. P.G. Hatfield. J.W. Bergman, \& C.R. Flynn. 2005. Supplemental safflower oil affects the fatty acid profile. including conjugated linoleic acid. of lamb. J. Anim. Sci. 83: 2175-2181.
Carneiro. C.F.H., V.R. Tonon, R.F.C. Grosso, \& D.M. Hubinger. 2013. Encapsulation efficiency and oxidative stability of flaxseed oil microencapsulated by spray drying using different combination of wall materials. J. Food Eng. 115:351-443.

Castillejos. L., S. Calsamiglia, A. Ferret, \& R. Losa. 2007. Effects of dose and adaptation time of a specific blend of essential oil compounds on rumen fermentation. Anim. Feed Sci. Tech. 132:186-201.

Castro. T., T. Manso, A.R. Mantecon, J. Guirao, \& V. Jimeno. 2005. Fatty acid composition and carcass characteristics of growing lambs fed diets containing palm oil supplements. Meat Sci. 69:757-764.

Chang. C. 2017. Encapsulation of omega fatty acid-rich oils using plant protein-based matrices. Tesis. Department of Food and Bioproduct Sciences. University of Saskatchewan. Canada.

Dutta. T.K., M.K. Agnihotri, \& S.B.N. Rao. 2008. Effect of supplemental palm oil on nutrient utilization, feeding economics and carcass characteristics in post weaned Muzafarnagari lambs under feedlot conditions. Small Rumin. Res. 78:66-73.

Eastridge. M.L. \& J.L. Firkins. 1991. Feeding hydrogenated fatty acids and triglycerides to lactating dairy cows. J. Dairy Sci. 74: 2610-2616.

Gatenby. R.M. 1986. Sheep Production in the Tropics and the Sub-Tropics. Longman. New York.

Gawad. R.M.A., M. Strabel, S.A. Abu El-Nor. H.M. Kattab. A. Cieślak, S.M. Kolif, \& M. Elnashar. 2015. Encapsulation method to protect unsaturated fatty acids from 
rumen biohydrogenation in vitro. JIOBS 2(3):240-251.

Hidayah, N. 2014. Ketahanan biohidrogenasi minyak nabati yang diproteksi dengan metode sabun kalsium dan mikroenkapsulasi secara in vitro. Tesis. Program Studi Ilmu Nutrisi dan Pakan. Sekolah Pascasarjana. Institut Pertanian Bogor. Bogor.

Hidayah, N., S. Suharti, \& I.K.G. Wiryawan. 2014. In vitro rumen fermentation of ration supplemented with protected vegetable oils. Med Pet. 37(2):129-135.

Hobson, P.N. 1988. The Rumen Microbial Ecosystem. Elsevier Applied Science. London.

Jenkins, T.C. 1993. Lipid metabolism in the rumen. J Dairy Sci. 76: 3851-3863.

Kearl, L.C. 1982. Nutrient Requirements of Ruminants in Developing Countries. $1^{\text {st }}$ Ed. Logan Utah (US): International feedstuffs Institute Utah Agricultural Experiment Station Utah State University.

Kronfeld, D.S., J.L. Holland, G.A. Rich, T.N. Meacham, J.P. Fontenot, \& D.J. Sklan. 2004. Fat digestibility in equus caballus follows increasing first-order kinetics. J Anim. Sci. 82:1773-1780.

Kurniawati, A., Widodo, W.T. Artama, \& L.M. Yusiati. 2018. Effects of Four Essential Oils on Nutrients Digestibility of In Vitro Ruminal Fermentation. Bull Anim. Sci. 42(2):122-126.

Lin, B., Y. Lu, A.Z.M. Salem, J.H. Wang, Q. Liang, \& J.X. Liu. 2013. Effect of essential oil combinations on sheep ruminal fermentation and digestibility of a diet with fumarate included. Anim. Feed Sci. Tech. 184:24-32.

Loor, J., J. Herbein, \& T. Jenkins. 2002. Nutrient digestion. biohydrogenation. and fatty acid profiles in blood plasma and milk fat from lactating Holstein cows fed canola oil or canolamide. Anim. Feed Sci. Tech. 97:65-82.

Lubis, D. \& E. Wina. 1998. Carcass production and meat quality of sheep fed high level of rumen bypass fat diets. Bull Anim. Sci. Suppl ed: 401-407.
Machmüller, A. \& M. Kreuzer. 1999. Methane suppression by coconut oil and associated effects on nutrient and energy balance in sheep. Can. J. Anim. Sci. 79:65-72.

Maia, M.O., I. Susin, E.M. Ferreira, C.P. Nolli, T.S. Gentil, A.V. Pires, \& G.B. Mourão. 2012. Intake. nutrient apparent digestibility and ruminal constituents of sheep fed diets with canola. sunflower or castor oils. R. Bras. Zootec. 41(11):23502356.

Messana, J.D., T.T. Berchielli, P.B. Arcuri, R.A. Reis, R.C. Canesin, \& A.F. Ribeiro. 2013. Rumen fermentation and rumen microbes in Nellore steers receiving diets with different lipid contents. R. Bras. Zootec. 42:204-212.

NRC. 2001. Nutrient Requirements of Dairy Cattle. $7^{\text {th }}$ Revised Edition. National Academy Press. Washington. D.C.

O'Brien, R.D. 2009. Fats and Oils Formulating and Processing for Applications 3rd Edition. CRC Press. New York.

Palmquist, D.L. \& T.C. Jenkins. 1980. Fat in lactation rations: review. J Dairy Sci. 63:1-14.

Preston, T.R. 1986. Better Utilization of Crop Residues and By-Products in Animal Feeding Research Guidelines. FAO Press. Roma.

Steel, R.G.D. \& J.H. Torrie. 1997. Principles and Procedures of Statistics. McGraw-Hill. New York.

Sudarman,. A. \& T. Ito. 2000. Heat production and thermoregulatory responses of sheep fed different roughage proportion diets and intake levels when exposed to a high ambient temperature. Asian-Aus. J. Anim. Sci. 13:625-629.

Sudibya, Darsono, \& P. Martatmo. 2009. Transfer Omega-3 melalui Kapsulisasi dan L-Karnitin pengaruhnya terhadap Komposisi Kimiawi Air Susu Sapi Perah. Laporan Hasil Penelitian Hibah Stranas. Fakultas Pertanian. Universitas Sebelas Maret. Surakarta.

Suharti, S., A.R. Nasution, D.N. Aliyah, \& N. Hidayah. 2015. Potensi minyak kanola dan flaxseed terproteksi sabun kalsium 
untuk mengoptimalkan fermentasi dan mikroba rumen sapi potong secara in vitro. Pros Sem Nas Masy Biodiv Indon. 1(1):89-92.

Suharti. S., D.N. Aliyah, \& Suryahadi. 2018. Karakteristik fermentasi rumen in vitro dengan penambahan sabun kalsium minyak nabati pada buffer yang berbeda. JINTP 16(3):56-64. 